\title{
175 - SORPTION AND LEACHING POTENTIAL OF ACIDIC HERBICIDES IN BRAZILIAN SOILS
}

\author{
Sorção e potencial de lixiviação de herbicidas ácidos em solos brasileiros. \\ SPADOTTO*, C.A. (EMBRAPA MEIO AMBIENTE, Jaguariúna-SP, spadotto@cnpma.embrapa.br); HORNSBY, \\ A.G. (UNIVERSITY OF FLORIDA, Gainesville-FL, USA); GOMES, M.A.F. (EMBRAPA MEIO AMBIENTE, \\ Jaguariúna-SP).
}

\begin{abstract}
Leaching potentials of three acidic herbicides were assessed for three different Brazilian soils, by means of the multi-layered AFi model. Values of AFi were also calculated for each herbicide using a modified model $\left(\mathrm{AFi}^{*}\right)$, where sorption coefficient $(\mathrm{Kd})$ values are $\mathrm{pH}$-dependent. The $\mathrm{pH}$-dependent $\mathrm{Kd}$ values estimated for all three herbicides were always higher than $\mathrm{pH}$-independent $\mathrm{Kd}$ values calculated using average Koc data. The $\mathrm{pH}-$ dependent $\mathrm{Kd}$ values for the three herbicides evidenced a large variation from layer to layer following changes in $\mathrm{OC}$ and $\mathrm{pH}$ for the different soil depths. When $\mathrm{OC}$ decreases, $\mathrm{Kd}$ tends to decrease; on the other hand, lowering $\mathrm{pH}$ tends to increase $\mathrm{Kd}$. For all three soils, $\mathrm{OC}$ and $\mathrm{pH}$ exhibit an overall decrease with depth. Despite differences between the $\mathrm{pH}$-independent $\mathrm{Kd}$ and the $\mathrm{pH}$-dependent $\mathrm{Kd}$ values, the $\mathrm{AFi}$ values for 2,4-D, calculated by the original multilayered-soil model and by the modified model $\left(\mathrm{AFi}^{*}\right)$, were similarly low for all three soils, mostly due to the short half-life of 2,4-D. The $\mathrm{pH}$-dependent $\mathrm{AFi}$ values for flumetsulam were always much lower than values calculated by the original multi-layered model. Therefore, the $\mathrm{pH}$-independent model appears to overestimate leaching potential of flumetsulam. The AFi values for sulfentrazone calculated by the original and the modified models were similarly high for all three soils, despite the differences in $\mathrm{Kd}$ values. The long half-life of sulfentrazone mostly contributed to the similar high values of AFi for the three different soils. Overall AFi values showed large differences for sulfentrazone when calculated by the original and by the modified model $\left(\mathrm{AFi}^{*}\right)$, owing to its high $\mathrm{AF}$ value for each layer. Thus, the original AFi model would seem to markedly overestimate the leaching potential for sulfentrazone, as well as for flumetsulam for these soil conditions.
\end{abstract}

Key Index Words: Multi-layered model, pH, 2,4-D, flumetsulam, sulfentrazone.

Palavras-chave: Modelo multi-camadas, $\mathrm{pH}, 2,4-\mathrm{D}$, flumetsulam, sulfentrazone.

\section{INTRODUCTION}

An understanding of herbicide sorption and transport processes in soil is essential to solve a number of problems facing agricultural and environmental scientists. The purpose of this study was to estimate sorption and to predict transport of acidic herbicides in soils, comparing the original and modified AF models for multi-layered soils (AFi).

\section{MATERIALS AND METHODS}

In this study, leaching potentials of three acidic herbicides, 2,4-D, flumetsulam, and sulfentrazone, were assessed for three different soils of the Ribeirão Preto region, State of São Paulo, Brazil. A total soil depth of $120 \mathrm{~cm}$ was considered, and the net recharge rate $(50 \mathrm{~cm} / \mathrm{yr}$.) in the watershed was estimated as the difference between rainfall $(150 \mathrm{~cm} / \mathrm{yr}$.) and evapotranspiration $(100 \mathrm{~cm} / \mathrm{yr}$.), assuming steady flow in the soil zone considered. Leaching potentials of the herbicides were assessed for multi-layered soils by means of the AFi model (Rao et al.,1985; Hornsby \& Rao, 1998). AF is defined as the fraction of the amount of herbicide applied at the soil surface that leaches through a given soil depth. Values of AFi were also calculated for each herbicide using a modified model $\left(\mathrm{AFi}^{*}\right)$ and parameters estimated as presented previously by Spadotto \& Hornsby (2003), where sorption coefficient $(\mathrm{Kd})$ values are $\mathrm{pH}$-dependent. Herbicide sorption coefficient $(\mathrm{Kd})$ values were calculated from literature data of sorption coefficient normalized for soil organic carbon content (Koc), and also estimated for 2,4-D, flumetsulam, and sulfentrazone in different layers of each soil.

\section{RESULTS AND DISCUSSION}

The $\mathrm{pH}$-dependent $\mathrm{Kd}$ values estimated for all three herbicides were always higher than $\mathrm{pH}$-independent $\mathrm{Kd}$ values calculated using average Koc data. The Kd values, as expected, were the lowest for the sandy soil (Typic Quartzipsamment), and highest for the clayey soil (Typic Haplorthox). The sandy soil has the lowest organic carbon (OC) content, while the clayey soil has the highest $\mathrm{OC}$ content. It is worth noting that the $\mathrm{pH}$-independent $\mathrm{Kd}$ values follow primarily the decrease of $\mathrm{OC}$ with depth. The $\mathrm{pH}$-dependent $\mathrm{Kd}$ values for the three herbicides evidenced a large variation from layer to layer following changes in $\mathrm{OC}$ and $\mathrm{pH}$ for the different soil depths. That is, Kd depends on a combined effect of these two soil parameters. When OC decreases, Kd tends to decrease; on the other hand, 
lowering $\mathrm{pH}$ tends to increase $\mathrm{Kd}$. For all three soils, $\mathrm{OC}$ and $\mathrm{pH}$ exhibit an overall decrease with depth. However, for the loamy soil (Quartzipsammentic Haplorthox) and clayey soil, OC contents do not vary largely below $60 \mathrm{~cm}$; thus, decreases in $\mathrm{pH}$ result in increasing $\mathrm{Kd}$ values for 2,4-D and flumetsulam. For the sandy soil, OC content continues to decrease with depth below $60 \mathrm{~cm}$, and 2,4-D and flumetsulam $\mathrm{Kd}$ values drop concurrently.

The $\mathrm{pH}$ effect on sulfentrazone sorption is shown to be very interesting. Because of its high $\mathrm{pK}_{\mathrm{A}}$ value (6.6), sulfentrazone $\mathrm{Kd}$ reaches a "maximum" value at higher $\mathrm{pH}$ values when compared with 2,4-D and flumetsulam. Thus, sulfentrazone Kd values do not increase when $\mathrm{pH}$ drops below $60 \mathrm{~cm}$ in all three soils. The AFi, expressed as percentage of herbicide mass applied at soil surface, was calculated for each soil. Despite differences between the $\mathrm{pH}$-independent $\mathrm{Kd}$ and the $\mathrm{pH}$-dependent $\mathrm{Kd}$ values, the $\mathrm{AFi}$ values for 2,4-D, calculated by the original multilayered-soil model and by the modified model $\left(\mathrm{AFi}^{*}\right)$, were similarly low for all three soils, mostly due to the short half-life of 2,4-D. The $\mathrm{pH}$-dependent AFi values for flumetsulam were always much lower than values calculated by the original multi-layered model. Therefore, the $\mathrm{pH}$-independent model appears to overestimate leaching potential of flumetsulam. The AFi values for sulfentrazone calculated by the original and the modified models were similarly high for all three soils, despite the differences in $\mathrm{Kd}$ values. The long half-life of sulfentrazone mostly contributed to the similar high values of AFi for the three different soils.

Overall AFi values showed large differences for sulfentrazone when calculated by the original and by the modified model (AFi*), owing to its high AF value for each layer - Figure 1. Thus, the original AFi model would seem to markedly overestimate the leaching potential for sulfentrazone, as well as for flumetsulam for these soil conditions. The herbicide sorption effect on degradation rate was not considered in this study. Greater sorption might lead to somewhat longer persistence of the herbicides in soils.

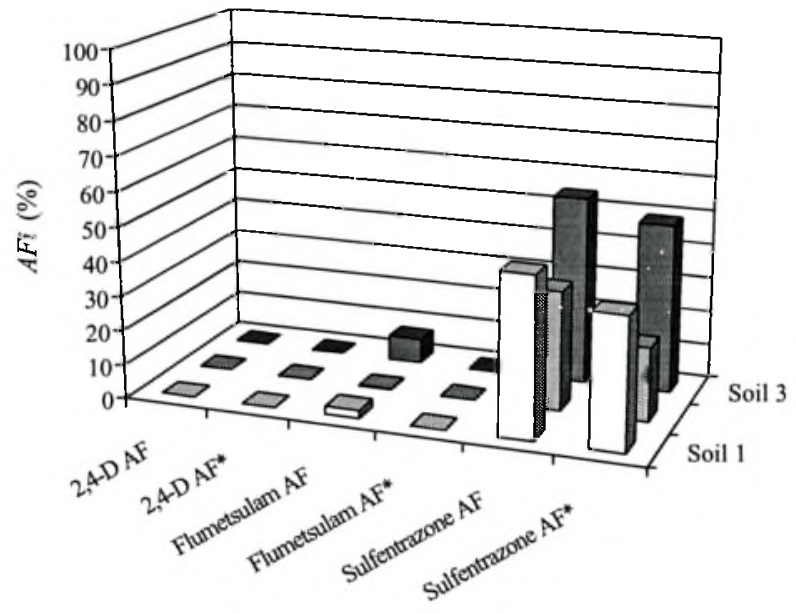

Figure 1. Overall pesticide Attenuation Factor values estimated by the original multi-layered model $(A F i)$ and by the modified model $\left(A F{ }^{*}\right)$ for Soil 1 (Quartzipsammentic Haplorthox), Soil 2 (Typic Haplorthox), and Soil 3 (Typic Quartzipsamment).

\section{REFERENCES}

HORNSBY, A.G.; RAO, P.S.C. Post publication addendum to Indices for ranking the potential for pesticide contamination of groundwater [Online]. Available at http://muck.soils.ufl.edu/ (posted 21 Jul. 1998; verified 16 Feb. 2004). 1998

RAO, P.S.C.; HORNSBY, A.G.; JESSUP, R.E. Indices for ranking the potential for pesticide contamination of groundwater. Soil Crop Sci. Soc. FL Proc., v.44, p. 1-8. 1985.

SPADOTTO, C.A.; HORNSBY, A.G. Soil sorption of acidic pesticides: Modeling pH effects. J. Environ. Qual., v.32, p.949-956. 2003. 